\title{
Molecular Genetic Method of Assessing Drought Tolerance in spring and Winter Wheat Seedlings
}

\author{
${ }^{1}$ Magash, A.I., ${ }^{3}$ V.K. Plotnikov, ${ }^{4}$ N.B. ${ }^{5}$ Bakaldina, J.B. and ${ }^{6}$ Alekseenko
}

\begin{abstract}
The research was conducted in the laboratory of molecular genetics, Krasnodar Agricultural Research Institute named after P.P. Lukyanenko to assess wheat varieties reaction to desiccation at molecular level grown under drought stress conditions. A total RNA preparation was isolated from spring and winter seedlings using phenol-detergent method, and the isolated poly (A) RNA were recovered from the total RNA using Affinity chromatography with poly Uracil sepharose as an absorbent. One of the objectives of the study is to adapt mini preparation procedure for the effective and rapid isolation of poly RNA, from total RNA preparation. Variable yields of poly (A) RNA were obtained, studied and analyzed from four days old seedlings of winter and spring wheat varieties, and the findings for tolerance to desiccation of wheat varieties, Krasnodarskaya-39, Olimpiya and Bezostaya-1 reacted differently to drought stress conditions, the variety Krasnodarskaya39 is highly tolerant to water stress while Olimpiya and Bezostaya-1 are moderately tolerant varieties at $\mathrm{P}<0.05$. These findings agreed with the direct and field assessment of wheat water stress-steadiness.
\end{abstract}

Keywords-Affinity chromatography, drought tolerance, isolation, phenol-detergent, poly ethylene glycol Stress steadiness, Uracil-sepharose, wheat.

\section{INTRODUCTION}

$\mathrm{A}_{\mathrm{p}}$ NALYSIS of the matrix RNA population has great practical perspective especially in crop production. The effect of desiccation and temperature, on the steady state of a particular mRNA which encodes specific protein for drought tolerance and key enzymes of metabolic activities, or the stress shock protein in tropical crop, will permit agronomist to carry an effective cultivars screening for drought tolerance thus consequently improving the crop productivity.[7,5]

Proteins play very important role in the life of every proand eukaryotic cell, they are the major constituents of cell's organelles, enzymes and hormones. They facilitate all biochemical and physiological process taking place in a living organism, which growth and development depend upon. [1,4]. While messenger RNA serves as a template for polypeptide translation. In general, the rate of synthesis of a protein usually depends upon the concentration of RNA that encodes it, thus, in turn is determined by a balance between the rate of mRNA synthesis and its decay. A high unstable mRNA is a

\footnotetext{
${ }^{1}$ Department of crop science Kano University of science and Technology, Wudil, Nigeria

3,4,5 and ${ }^{6}$ laboratory of molecular genetics, Krasnodar Agricultural Research Institute named after P.P. Lukyanenko.
}

prerequisite for the rapid chain regulation of protein synthesis shortly after the transcription of a particular mRNA ceased. It's important to note that the variation in the steady state of cytoplasmic mRNA determines the adaptation of an organism to its peculiar habitat. [1, 2,8]. The regulation of gene expression at mRNA stability level will obviously continue to be an important focus of biological research. Further studies of the mechanism and structural determination of mRNA decay should in time bring significant new insight. [10, 12, 11]

The main objective of this experiment is to study the regulation of gene expression at the stability level of mRNA from wheat seedlings which were prior subjected to drought stress; hence the following specific objectives were set:

- Isolation of total RNA preparation from spring and winter wheat seedlings using phenol-detergent method

- Isolation and analysis of poly (A)+ mRNA content from total preparation using the method of affinity chromatography on poly (U) sepharose

- Study the effects of desiccation on poly (A)++ yield from spring and winter wheat seedlings.

\section{MATERIALS AND METHOD}

\section{A. Condition of raising the seedlings}

Wheat cultivars Seleksia KNII were three times washed thoroughly with water to remove none viable seeds and other impurities. Sowing of seeds was carried out on Yokovsona's table which is made up of seed trays; three quarter full of water covered with a wire-gauge and filter paper was placed whereon sowing was carried. A spacing of $10 \times 19 \mathrm{~cm}$ was made (an area within which seeds were sown). The sown seeds were then covered with humidified and perforated filter paper to facilitate germination and ventilation. To prevent light from inhibiting the seed's germination, some plastic containers were used to cover the seeds. The whole set was then placed in a controlled camera under 20 0c for three days to allow germination. On the fourth day, the sprouted seeds were transferred to plastic containers. This was carried out by cutting out the sown seed area carefully without damaging rootlets and placing it into a plastic container provided for this purpose. Each container was labeled prescribing the type of experiment and wheat variety used. The whole containers were kept in phytotrone for about 9 hours under bright light condition.

The Seedlings were treated with the solution of $0 \%, 10 \%$ and $12 \%$ polyethylene glycol and kept for 24 hours. The 
cutting of the seedlings were carried and sample was stored in chilled liquid Nitrogen

\section{B. Isolation of total RNA phenol detergent method}

The (stored in chilled liquid Nitrogen) seedlings were grounded to a fine state in a liquid Nitrogen using a mortar and pestle and defatted by buffer at ratio1: 5 . The buffer solution of $0.2 \mathrm{M}$ tris $\mathrm{HCL}, \mathrm{PH} 8.5,0.05 \mathrm{M} \mathrm{MgCL}, 2 \%$ Sodium dodecyl sulphate was used. A chilled phenol / chloroform was added at 1:1 and mixed for 20 minutes at room temperature on a shaker Sh-4 premed (Poland). All the proteins were removed as SDS/ KOAC precipitates by centrifugation of the homogenates at $300 \mathrm{~g}$ for 20 minutes on centrifuge $\mathrm{K} 23 \mathrm{D}$ MLW (Germany) at 40 C. Supernatants were collected in a test tube of equal volume of phenol-chloroform and second deproteinization was repeated. The collected supernatant from second deproteinazation was mixed with 2.2 volume of absolute ethanol shaken and left for 2 hours.

After centrifugation at normal procedure precipitated nucleic acid were collected and dissolved in distilled water at $1 \mathrm{ml}$ per $1 \mathrm{~g}$ of the precipitate and an equal volume of deproteinization solution was added $(8 \mathrm{~m} \mathrm{LiCl} 8$ urea and $4 \mathrm{mM}$ EDTA) this was kept for 16 hours at $4^{0} \mathrm{C}$. The pellets were collected by sedimentation after centrifugation washed with enough volume $300070 \%$ of ethanol and centrifuged for 10 minutes again. [13] Spirit was used to wash the pellets and dried it in vacuum KPG-1M (Russia) and resuspended in 3.0 $\mathrm{ml}$ water and centrifuge for 30 minutes at $3000 \mathrm{~g}$. RNA samples can also be extracted using the TRIZOL method (INVITROGEN) from seedlings as described before [19, 18]

The supernatants that contain RNA were transferred to a glass cube and stored at $-20{ }^{\circ} \mathrm{C}$. mRNA yield was calculated based on the observation that $1 \mathrm{mg}$ RNA in low salt absorbs 25 optical density (OD) at $260 \mathrm{~mm}$ and the spectrophotometrical characteristic of RNA preparation was $260 / 280=2.0$; $260 / 230=2.1$, absorbance ratio of 1.8 or greater indicated level of purity which correlated well with subsequent restriction endo-nuclease digestibility at RNA in the extract.

\section{Isolation of poly (A) RNA (Affinity chromatography method)}

Chromatograph was carried on wet chromatography 0.34 Hitach (Japan) that consist of thermostat, glass tube and pump, with affinity absorbent (Poly Uracil sepharose), which was sensitive to poly-adenine RNA. The chromatography was connected with circulation water in a water basin.

The stored preparations of total RNA was mixed with an equal volume of buffer $40 \mathrm{mM}$ tris HCL pH $7.61 \mathrm{LiCl} 0.2 \%$ SDS and shaken and then poured in to the glass column of chromatograph. Initially the glass tube was washed with this buffer to the time of no absorbance of optical density at 260 $\mathrm{nm}$ when the run down buffer was absorbed in the spectrophotometer. The same process was carried with the RNA preparation 2-3 times. [13]

All the none specific RNA were washed down, since they will not react with the poly (U) sepharose in the chromatography glass tube. The release of poly (A) RNA was conducted by passing warm water at $650 \mathrm{C}$ through the chromatography glass tube. All the content of the affinity tube was collected in a bottle and the concentration of Poly (A) RNA was determined at $260 \mathrm{NM}$ on a spectrometer Specord m400. [13] To determine the RNA period of half life (turnover) it is necessary to run the second circle of affinity chromatography of poly (A)+ RNA from the first circle. The percentage of poly (A) RNA yield after second circle from the first circle taking first circle as $100 \%$ was determined. This shows the RNA stability.

The experiment was repeated about 3 times and the value of experimental error was determined at $\mathrm{P}<0.05$.

\section{RESUlts AND DISCUSSION}

The method of affinity chromatography was found to be an effective and simple scientific technique of studying matrix RNA turn over. The principle of the method is releasing specific RNA from none specific RNA using a sensitive absorbent, and the percentage of the stable RNA which are resistant to turn over was determined by carrying a second circle of chromatography. RNA turn over depends upon the physiological state of the source crop as affected by different endo and exodermic factors). This study discovered that some of the factors that influence RNA turn over, include desiccation, temperature and other growing conditions.

In this study different cultivars of winter wheat and winter barley were studied. The yield of poly (A) RNA correlated clearly with the cold-steadiness. Seedlings raised at $4^{0} \mathrm{C}$ gave various yield of poly (A) RNA depending on the level of coldsteadiness of each cultivars (table.1) The analysis of the variable yield of poly (A)++ RNA (second circle) from poly (A)+ RNA (first circle) revealed that the yield depend tightly on the physiological state of the plant, which is subjected to change under the influence of temperature and desiccation.

It was discovered that, the integral index of plant reaction to exogenic and endogenic factors is found to be correlated with plant growth intensity.[14]

Many years research on critical trait in the adaptation of temperate grasses to cold winters revealed the fact that long exposures to low temperatures (vernalization) accelerate flowering. The vernalization requirement in temperate grasses is mainly controlled by allelic variation at the vernalization genes VRN1 and VRN2 [3, 6,17,18, 19].

The findings of the effect of temperature on winter wheat (table.1) indicates that, wheat cultivars distinguish themselves in terms of rate of their reaction to temperature . [15] All spring and winter cultivars responded differently to temperature. Seedlings raised at $4^{0} \mathrm{C}$ gave various yield of poly (A) mRNA depending on the level of cold-steadiness of each cultivars

Temperature as an important exogenic factor that all life depends on, its effect on mRNA stability was observed on 3 wheat varieties (Table-1) The varieties were sown at various temperature conditions $4,20,25,26,40$ and $60^{\circ} \mathrm{C}$. The minimum RNA yield was observed in the 3 varieties at $20^{\circ} \mathrm{C}$ and any deviation of the temperature to either direction caused an increment in mRNA yield, which revealed that the seedlings performed well at $4{ }^{\circ} \mathrm{C}, 23^{\circ} \mathrm{C}$ and $26^{\circ} \mathrm{C}$. This is an indication that mRNA became stable on the effect of stress temperature, thus gradual decrease/increase might have allowed organism to 
adapt to the unfavourable conditions. Research has revealed the fact that gradual exposure of an organism to stress condition a new gene of stress shock protein is born thus enabling organism to adapt to the stress condition. The stress shock proteins also enable the other gene to be stabilized and prevent their turn over (decay) [9,15]. It is difficult to explain why a very low temperature of 4 stabilized the gene, this needs a further study and investigation but yet this will remain as a fact.

In this study different cultivars of winter wheat were studied. The yield of poly (A)mRNA correlated clearly with the desiccation intensity. The best method of evaluating cultivars for drought tolerance and desiccation is a direct field and more effective assessment if this problem is check at molecular level.

The analysis of mRNA yield from 3 winter wheat that grown at $20^{\circ} \mathrm{C}$ and subjected to desiccation within 5 hours shows that the high yield of mRNA was obtained from Krasnodarskaya-39 with about 57\% as compared with control variant. Bezostaya-1 has the least yield of only 5\% (Fig.2) judging from these findings, Krasnodarskaya-39 is highly tolerant to desiccation at physiological level thus, $57 \%$ of its mRNA has been stablised. while Bezostaya-1 is moderately tolerant ( $5 \%)$.

The analysis of mRNA from the seedlings under temperature and water stress condition show that the period of mRNA half life decay is determined by studying the period of mRNA turn over at second circle when compared with the first circle of affinity chromatography. The mRNA yield quantity that was retained after second circle showed the stability status of the gene exposed to stress conditions. This indicates that the stable the gene, the effective its expression and directly proportional to plant growing conditions.

TABLE I

The EFFect Of Temperature ON POLY A++ MrNa Yield From Winter AND SPRING WhEAT SEEDLINGS, ${ }^{0} \mathrm{C}$

\begin{tabular}{|c|c|c|c|c|}
\hline varieties & & $\begin{array}{c}\text { Temper } \\
\text { ature, }{ }^{0} \mathrm{C}\end{array}$ & & \\
\hline & $04^{*}$ & 20 & 23 & 26 \\
\hline Krasnodarskaya 39 & $60 \pm 03$ & $14 \pm 01$ & $36 \pm 02$ & $75 \pm 02$ \\
\hline Olimpia & - & $18 \pm 0.8$ & $33 \pm 02$ & $73 \pm 02$ \\
\hline Bezostaya I & $44 \pm 01$ & $25 \pm 01$ & $31 \pm 02$ & $49 \pm 01$ \\
\hline
\end{tabular}

$\mathrm{P}<0.05$

Results are mean \pm standard deviation, a figure that differ significantly at $\mathrm{P}<$ 0.05

Key:

Poly A = poly adenine matrix RNA

$+=$ first circle of affinity chromatography for determining mRNA half life period of decay

$++=$ second circle of affinity chromatography for determining mRNA half life period of decay.

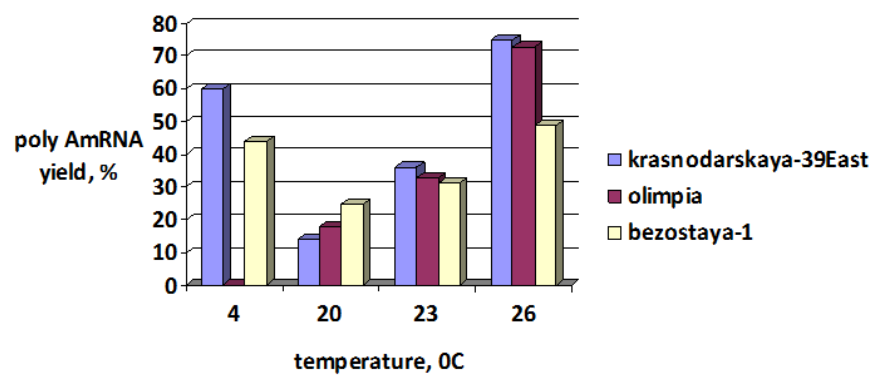

Fig. 1 The effect of temperature on Poly A mRNA from winter and spring wheat seedlings

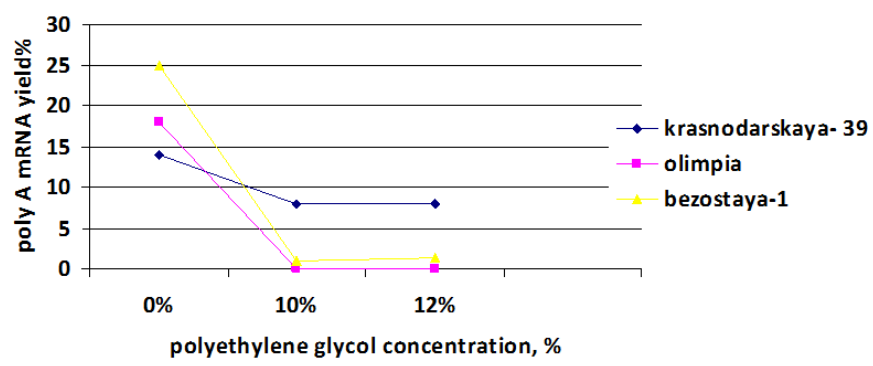

Fig.2 Effect of desiccation on the yield of poly A mRNA from winter wheat seedlings

\section{CONCLUSION}

The method of molecular genetics helps in reducing the period taken by conventional plant breeding to evaluate markers of resistance to stress conditions in plant or to introduce a new variety of plants resistant to diseases, pests and other unpleasant climatic factors with high productivity, to less than one-third of normal duration. This research finding revealed the fact that Wheat growth intensity and adaptability to stress conditions depend on the mRNA stability, which produces the corresponding proteins responsible for this physiological and biochemical readjustment. Therefore it's very important to study the measures of regulating mRNA stability and the effect of its turnover in genes expression.

\section{REFERENCES}

[1] Anne, S., Michael B. and Don W. (1989). Differential expression within a family of novel wound induced genes in potato: Molecular genetics, 219, 200-203

[2] Arbuzov, V.A. (1980). Osobennosti Metabolisma mRNA v opukholevih kletkah. Uspeh biohimiya 21, M. Nauk, , 79-80

[3] Dubcovsky, J., Chen, C. and Yan, L. 2005. Molecular characterization of the allelic variation at the VRN-H2 vernalization locus in barley. Mol. Breeding 15: 395-407

http://dx.doi.org/10.1007/s11032-005-0084-6

[4] Dolars, M., Luis L. and Aviln R. (1990). Expression of genes for cell protein in dividing and wounded tissue od Zea mays. Planta 180, 524529.

http://dx.doi.org/10.1007/BF02411450

[5] Gayle, L., Ferene, M., and Hamna C. (1989). Light regulated and organospecific expression of wheat cab gene in transgenic tobacco. Nature, V. 318, P.22-27

[6] Jensen, L.B., Andersen, J.R., Frei, U., Xing, Y.Z., Taylor, C., Holm, P.B. and Lubberstedt, T.L. 2005. QTL mapping of vernalization response in perennial ryegrass (Lolium perenne

[7] Kakoto H., Toshiaki M. and Takashi A. (1989). Regulatory role of Ca+ on the level of aamylase mRNA in rice seed. Plant physiology. Biochemistry, .27, 37, 349-354 
[8] Khozhin, A.J., Doschanov, M.A. and Akachanov, A.U. (1976). Informosomes as a stored form of mRNA in wheat embryo. FEEBS Lett.. V.66, P.124-126 http://dx.doi.org/10.1016/0014-5793(76)80600-X

[9] Lanks, K.W. (1988). Modulator of the eukaryotic heat shock response. Exp. Cell. 185. 1-10

[10] Matthias, W. (1991). Hentze determinants and regulation of cytoplasmic mRNA stability in eukaryotic cells. Bioch. et Biophys., 1090, 281-292

[11] Mertbasov, M.P. (1990). Regulation of gene expression. Phys, biochem. Plant, 103, 264- 269

[12] Mullet, J., Klein, R.K. (1983). transcription and RNA stability are important determinants of higher plant chloroplast RNA level. EMBO journal, 6, 6, 1571-1579

[13] Poulson, R. (1973). Isolation, purification and fractionalization of RNA In the Ribonucleic acid. Berlin, 243-261

[14] Sachs, M.M. Hot, A.D.( 1986). Alteration of gene expression during environmental stress in plant. Annu. Rev. plant Physiol., 37, 363-385 http://dx.doi.org/10.1146/annurev.pp.37.060186.00205 1

[15] Salandra, J.J. Subjeet, J.(1983)/. Effect of glucose on protein synthesis and thermosensibity in chinese chamster ovary cell. J. biochem., 258, 20, 12091-12093

[16] hompson, D.M. and Meager, R.B.(1990). Transcription and posttranscriptional processes regulate expression of RNA encoding the small subunit of ribulose 1,5-biphosphate carboxilase in petunia and in soybean. Nuc. Acid, res., 18, 12, 3621-3629

[17] VonZitzewitz, J., Szu^ cs, P., Dubcovsky, J., Yan, L., Francia, E., Pecchioni, N., Casas, A., Chen, T.H.H., Hayes, P.M.and Skinner, J.S., 2005. Molecular and structural characterization of barley vernalization genes. Pl. Mol. Biol. 59: 449-467. http://dx.doi.org/10.1007/s11103-005-0351-2

[18] Yan, L., Loukoianov, A., Blechl, A., Tranquilli, G., Ramakrishna, W., SanMiguel, P., Bennetzen, J.L., Echenique, V. and Dubcovsky, J. 2004b. The wheat VRN2 gene is a flowering repressor down-regulated by vernalization. Science 303: 1640-1644. http://dx.doi.org/10.1126/science.1094305

[19] Yan, L., Loukoianov, A., Tranquilli, G., Helguera, M., Fahima, T. and Dubcovsky, J. 2003. Positional cloning of wheat vernalization gene VRN1. Proc. Natl. Acad. Sci. USA 100: 6263-6268. 480. 